\title{
Rational Choice of Following Muhammadiyah and Nahdlatul Ulama and Their Social and Political Role in Indonesian Society
}

\author{
Abdullah M. Al-Ansi' ${ }^{1}$, Ishomuddin ${ }^{2}$, Tri Sulistyaningsih"2, Rinikso Kartono² \\ ${ }^{1}$ Social and Political Science Department, UMM, Malang, Indonesia \\ ${ }^{2}$ Faculty of Social and Political Science, UMM, Malang, Indonesia \\ Email: ebrar.ansi@yahoo.com
}

How to cite this paper: Al-Ansi, A.M., Ishomuddin, Sulistyaningsih, T. and Kartono, R. (2019) Rational Choice of Following Muhammadiyah and Nahdlatul Ulama and Their Social and Political Role in Indonesian Society. Open Access Library Journal, 6: e5829.

https://doi.org/10.4236/oalib.1105829

Received: October 5, 2019

Accepted: November 22, 2019

Published: November 25, 2019

Copyright $\odot 2019$ by author(s) and Open Access Library Inc.

This work is licensed under the Creative Commons Attribution International License (CC BY 4.0).

http://creativecommons.org/licenses/by/4.0/

\begin{abstract}
Muhammadiyah and Nahdlatul Ulama are the biggest Islamic social organizations in Indonesia with more than 70 million adherents. Both two organizations were founded in the early 19th century. This study aims to describe the main features and characteristics of Muhammadiyah and Nahdlatul Ulama to understand the reasons of followers behind joining one of these two organizations and to describe the role of two organizations on social and political aspects of Indonesian society. This study is categorized under social definition approach. Based on the subject and objectives of this study, phenomenological type was the suitable approach to conduct this study in addition to in-depth explanation and illustration of two organizations. Qualitative method with purposive sampling was used to collect data by interviews and documents of both organizations. Characteristics of Muhammadiyah and Nahdlatul Ulama could be divided into two types: common and different characteristics. Muhammadiyah and NU are similar in social service, religious orientation and Islamic education. Both organizations share the same Islamic values regardless some differences in doctrines. There are some differences that Muhammadiyah is considered as Modern organization, revolutionary and renewal movement while NU has strong believe in the founder's thoughts where no change in the basics of these thoughts and modern in education, politics and some social activities. Rational choice was based on five factors which are values of the organization, family background, education, society orientation and related benefits. Values of the organization and education have the priority in Muhammadiyah while family and values have the priority in Nahdlatul Ulama respectively. Muhammadiyah and Nahdlatul Ulama have a significant impact on the Indonesian Muslim society by holding religious activities, education, cultural events and charity. In addition,
\end{abstract}


both organizations play important role in conducting socio-religious and socio-cultural occasions. Muhammadiyah and Nahdlatul Ulama are not political parties but they play a significant role in shaping the Indonesian politic. Activists of both organizations have formed political parties but not all followers of the both organizations follow these parties.

\section{Subject Areas}

Politics, Sociology

\section{Keywords}

Muhammadiyah, Nahdlatul Ulama, Rational Choice, Islamic Social Organizations

\section{Introduction}

Nahdlatul Ulama and Muhammadiyah are the biggest local Islamic organizations in Indonesia with more than 70 million adherents. Both two organizations were founded in the early 19th century. Majority of Indonesian people are Muslims. According to Central Bureau of Statistics, in the 2010 Indonesian census, 87.18\% of Indonesians identified themselves as Muslim (with Sunnis more than 99\%, Shias 0.5\%, Ahmadis 0.2\%) [1]. 207 million of populations are Muslims while 70 million of them are adherents of Muhammadiyah and Nahdlatul Ulama.

In Indonesian history, especially from the pre-Independence period to the present, position and role of Islamic organizations are quite important to the process of changing social societies. Ulama are the role models for Islam, which is the largest religion in Indonesia. Although government is secular where religion is basically independent, it is theoretically and dogmatically involved in the interrelationships with social, economic and political realities [2]. There is a need to understand the major role, thoughts, formation and direction for the two organizations to understand the role of Islam as a religion and a major driver of social, cultural, economic and political life of Muslims in Indonesia and country. In addition, these two organizations have published their thoughts and approaches based on the Islamic thoughts. As a result for that, this study will include theoretical review about two Islamic organizations and their schools to understand and describe the roots and basics of Muhammadiyah and Nahdlatul Ulama. The role of these two organizations in implementing Islamic schools and building the social and cultural life of Indonesian people in addition to shaping the political aspects is very interesting issue to study and identify the strength and weakness sides of them to give an ideal example for other Islamic countries.

Following of Muhammadiyah and Nahdlatul Ulama is a social and political phenomenon. Adherents of these social Islamic organizations have many religious, social and political benefits. Their rational choice is based on these bene- 
fits and goals. This study illustrates the reasons behind joining these two organizations based on the rulers and followers of Muhammadiyah and Nahdlatul Ulama. Rational choice is attempt to explain all (agreement or disagreement) social phenomenon in terms of how self-interested individuals make choices under the influence of their preferences. It treats social and political exchange as similar to economic exchange where individuals try to maximize their advantage or gain, and to minimize their disadvantage or loss. Actually, human beings take their decisions based on their rational calculations. They try to maximize their profits and interest. A number of social scientists (Coleman, Elster, Kahneman \& Tversky, Sen, Simon, Thaler and Sunstein, among many others), drawing on psychology and the cognitive sciences along with anthropology and sociology, have brought greater realism, empirical relevance, and moral direction to the rational choice approach [3].

Muhammadiyah and Nahdlatul Ulama play an important role in the social and political aspects of Indonesian society. Every society is impacted by individuals and sects with different culture, attitudes, race, religions, traditions and many other elements. Islamic organizations are impacting societies based on Islamic traditions and instructions. Political aspects of Islam are derived from the Qur'an, the Sunnah (the sayings and living habits of Prophet Mohammed), Muslim history, and elements of political movements outside Islam. Islamic organizations impact on social life by many elements such as education, social and religious activities and charity. The preservation of a social order depends on each and every member of that society freely adhering to the same moral principles and practices. Islam, founded on individual and collective morality and responsibility, introduced a social revolution in the context in which it was first revealed. Collective morality is expressed in the Qur'an in such terms as equality, justice, fairness, brotherhood, mercy, compassion, solidarity, and freedom of choice.

Muhammadiyah and Nahdlatul Ulama as the biggest Islamic organizations in Indonesia and their important role of driving religious, social and political life in the country peacefully is a unique phenomenon. These two organizations play a significant role in shaping Indonesian Islamic thoughts. There is a persistent need to study and clarify the role of these two organizations and their unique characteristics. Conflicts of some Islamic sects in many Islamic countries led to serious problems for these countries while the opposite is in Indonesian Islamic organizations. This study will describe and classify two of the biggest Islamic organizations according to their reason of existence and perception of Islam, rationality of adherents, their role on the social and political aspects of Indonesian society. Muhammadiyah and Nahdlatul Ulama are an ideal example of Islamic social organizations around the world. Merging local culture, social and political activities with Islam and keeping them at the same row without conflicts in an advantages and a role model for any Islamic country. Rational Choice of following Muhammadiyah and Nahdlatul Ulama have is significant to understand the purpose of following such Islamic organizations and to generalize the idea of the 
other Islamic organizations around the world.

This study shows the role of the biggest Islamic Organizations in Indonesia based on their understanding of Islamic religion, Ideology in social and political aspects of the society. This study also finds the reason behind the rational choice of followers to join one of these two organizations. This study shows the impact of both Islamic organizations on social and political aspects of Muslims life in Indonesia. In addition to the changes of Islamic communities as a result of ruling these organizations for education, religious activities, social and political in the country.

\section{Literature Review}

Muhammadiyah and Nahdlatul Ulama are identified as social-religious organizations. Islamic religion is the main dynamo behind formation and joining these two organizations. Majority of Indonesian Muslims are not following any jurisprudence schools and they consider themselves as normal Muslims. Based on demographic statistics, 99\% of Indonesian Muslims mainly follow the Shafi'i school, although when asked, 56\% does not adhere to any specific school [4]. Orientations of Muslims in Indonesia could be categorized under two main schools which are modernism and traditionalism. The representative of modern school is Muhammadiyah and tradition school is Nahdlatul Ulama.

There are many studies included some important aspects of Muhammadiyah and Nahdlatul Ulama in Indonesia. But this study included four important aspects which are religious, rational, social and political aspects. Ishomuddin (2014) [5] showed the social, cultural and political change of the two organizations while this study shows the rational choice of the followers to join both organizations and the social and political impact of Muhammadiyah and Nahdlatul Ulama on the Indonesian society (Ishomuddin, 2014). Mathema (2015) has concluded that minorities societies in Indonesia are excluded and marginalized by the biggest social organization such as Nahdlatul Ulama during the process of democratization while this study will give an explanation how the role of both Muhammadiyah and Nahdlatul Ulama in the political aspects in the Indonesian society (Mathema, 2015). Fauji Kuda study about the founder of Muhammadiyah and his role of forming social life of the Indonesian society is including the thoughts and social aspect [6]. There is important study in the same field which is titled as a century of NU-Muhammadiyah in Indonesia: the failure of Islamic modernism by Moeflich Hasbullah. Hasbullah's study showed the different approaches of Muhammadiyah and NU in implementing their visions and instead of modernization of the Islamic thoughts and society, they build their own way of improvement. This study differs from Hasbullah's study to describe and explain role of both organization in religious activities, social and political activities of them [7].

Rational choice of following organization has economic or political reasons. In case of social Islamic organization, religious motivator is the main reason in addition to economic or political reasons. The rational choice approach treats 
behavior as purposive: individuals have goals and make choices intended to achieve their goals. This emphasis on goals and choices contrasts with sociological and psychological approaches that treat behavior as a response to organizational norms, social pressures, or inner drives [8]. Rational choice theory is the most serious attempt to fully acknowledge the normativity that is crucial to intentional explanation, and the subjective meanings that play their indispensable role in behavioral and attitudinal rationality, without giving up the aim of a unified science-based on erklären. The hope of rational choice theory is to explain and predict human action in terms of laws that causally relate expected utility numbers and ensuing actions [9].

Social factors are the facts and experiences that influence individuals' personality, attitudes and lifestyle. Social factors are things that affect lifestyle, such as religion, family, education, economy, culture or wealth. These can change over time. 1) Social Occasions: Islam has relatively few holidays compared to most other religions; nevertheless, sacred days and times are very important to Muslims. When holidays are being observed, it is common for routine social activities, such as work and commerce, to stop temporarily out of respect for the person or event being remembered. Most Islamic holidays either commemorate events in the life of the prophet Muhammad or are special days founded by him. The popular festival of Mawlid an-Nabawi celebrates the birthday of the prophet Muhammad, but is frowned upon as an idolatrous innovation by conservative Muslims. 2) Education: Education is the most powerful instrument of social change. It is through education that the society can bring desirable changes and modernize itself. Education can transform society by providing opportunities and experiences through which the individual can cultivate himself for adjustment with the emerging needs and philosophy of the changing society. A sound social progress needs careful planning in every aspect of life-social, cultural, economic and political. Education must be planned in a manner that is in keeping with the needs and aspirations of the people as a whole. The relationship of education with social change is not a simple, unilateral one, as perhaps many would like to believe, for education is not only instrumental in bringing about social change, it is also quite interestingly instrumental in maintaining the status quo. In other words, education plays with a "conservative" and radical role, i.e. it helps both in "maintaining" and changing different aspects of the social system. 3) Religious Occasions: Traditionally, Muslims observe two major festivals ("Id Al-Fitr" and "Id Al-Adha") and one month of daytime fasting (Ramadan). There is also a day of voluntary fasting: "Ashura" which is also an important Shiite festival. 4) Economy: Economy is an important factor in social behavior. Social economy studies the relationship between economy and social behavior. It analyzes how consumer behavior is influenced by social morals, ethics and other humanitarian philosophies. The social economy examines activity that is related to economics amongst the community and exposes the information to the community, this includes the social enterprise and voluntary sectors [10]. 5) Culture: Culture not only influences our social relationships, it also influences 
the direction and character of technological change. It is not only our beliefs and social institutions which must correspond to the changes in technology but our beliefs and social institutions determine the use to which the technological inventions will be put in. 6) Charity: Charity is very important in Islam, and even more so during Ramadan. Zakat, often translated as "the poor-rate", is obligatory as one of the pillars of Islam; a fixed percentage is required to be given to the poor of the person's savings. Sadaqa is voluntary charity in given above and beyond what is required from the obligation of Zakat. In Islam all good deeds are more handsomely rewarded in Ramadan than in any other month of the year.

Political theory is the study of the concepts and principles that people use to describe, explain, and evaluate political events and institutions. Traditionally, the discipline of political theory has approached this study from two different perspectives: the history of political thought, and contemporary political philosophy. Muhammadiyah and Nahdlatul Ulama were established at the beginning of the 19Th century. During this period till now, Indonesia had different political systems such as colonial authorities, old order, new order, post new order or (parliamentary elections and presidential elections). This study shows the role of Muhammadiyah and Nahdlatul Ulama during these periods. 1) Colonial Era: This era started from the Portuguese, Dutch, French and British interlude and Japanese. In October 1908, the first nationalist movement was formed, Budi Utomo. On 10 September 1912, the first nationalist mass movement was formed: Sarekat Islam [11]. The Dutch responded after the First World War with repressive measures. The nationalist leaders came from a small group of young professionals and students, some of whom had been educated in the Netherlands. In the post-World War I era, the Indonesian communists who were associated with the Third International started to usurp the nationalist movement [12]. The Japanese invasion and subsequent occupation during World War II ended Dutch rule and encouraged the previously suppressed Indonesian independence movement. In May 1940, early in World War II, the Netherlands was occupied by Nazi Germany [13]. In March 1945, the Japanese established the Investigating Committee for Preparatory Work for Independence (BPUPK) as the initial stage of the establishment of independence for the area under the control of the Japanese 16th Army [14]. Sukarno and Hatta proclaimed Indonesian independence on 17 August 1945, two days after the Japanese Emperor's surrender in the Pacific. 2) Liberal Democracy Period: With the unifying struggle to secure Indonesia's independence over, divisions in Indonesian society began to appear. These included regional differences in customs, religion, the impact of Christianity and Marxism, and fears of Javanese political domination. Following colonial rule, Japanese occupation, and war against the Dutch, the new country suffered from severe poverty, a ruinous economy, low educational and skills levels, and authoritarian traditions [15]. With the support of the military, Sukarno proclaimed in February 1957 a system of "Guided Democracy", and proposed a cabinet representing all the political parties of importance. 3) The New Order: 
Sukarno's position depended on balancing the opposing and increasingly hostile forces of the army and the PKI. Sukarno's anti-imperialist ideology saw Indonesia increasingly dependent on Soviet and then communist China. By 1965, the PKI was the largest communist party in the world outside the Soviet Union or China. Penetrating all levels of government, the party increasingly gained influence at the expense of the army. In 1996 Suharto undertook efforts to pre-empt a challenge to the New Order government. Within a few years, however, many of its original allies had become indifferent or averse to the New Order, which comprised a military faction supported by a narrow civilian group. Among much of the pro-democracy movement which forced Suharto to resign in the 1998 Indonesian Revolution and then gained power, the term "New Order" has come to be used pejoratively. It is frequently employed to describe figures who were either tied to the Suharto period, or who upheld the practices of his authoritarian regime, such as corruption, collusion and nepotism. 4) Reform Era: Suharto stood for re-election by parliament for the seventh time in March 1998, justifying it on the grounds of the necessity of his leadership during the crisis. The parliament approved a new term. This sparked protests and riots throughout the country, now termed the Indonesian 1998 Revolution. Dissent within the ranks of his own Golkar party and the military finally weakened Suharto, and on 21 May he stood down from power. He was replaced by his deputy Jusuf Habibie. In October 1999, the People's Consultative Assembly (MPR), which consists of the 500-member Parliament plus 200 appointed members, elected Abdurrahman Wahid, commonly referred to as "Gus Dur", as President, and Megawati Sukarnoputri as Vice-President, both for five-year terms.

This study is important to show the rational choice of Indonesian people to follow such organizations, reasons and benefits of following them. These two organizations established before a century and implemented many important ideas in education, economy, culture and social life of Indonesian people. There is need to understand a phenomena of these Islamic social organization as the biggest local Islamic organizations in the world, to understand the differentiations between them and to show their role of building social and political movements of the Indonesian society.

\section{Method}

This study is categorized under social definition approach. Based on the subject and objectives of this study, phenomenological type was the suitable approach to conduct this study in addition to in-depth explanation and illustration about two biggest Islamic Indonesian organizations (Muhammadiyah and Nahdhatul Ulama).

\subsection{Approach of Study}

Qualitative method was used as a method approach to conduct this study about two Islamic organizations. As long as the aim of this study is to study both organizations Muhammadiyah and Nahdlatul Ulama, qualitative method was the 
best method to describe the main features and characteristics of two Islamic organizations in Indonesia and their religious, social and political impact on the Indonesian society. This study also conducted by using qualitative approach which includes interviews and other research methods to fulfill the research objectives and solve the problem of study. Qualitative method will be used to understand the reason behind choosing joining in these two organizations.

\subsection{Data Source}

There are two sources of data in this study. Primary data was collected by interviews and secondary data was collected by documents and other sources. Primary data was collected by conducting interviews with specialists and followers of Muhammadiyah and Nahdlatul Ulama in Indonesia beside the observations of the researcher. Primary data included the answers questions of the study. While the other data about in-depth explanation and supporting the answers were collected from previous studies in the field, documentaries, researches centers and other sources.

\subsection{Data Collection Method}

Interviews were conducting with head of office for both organizations in Malang city, researchers and followers of Muhammadiyah and Nahdlatul Ulama. In addition to the interviews, there is another approach of collecting data in this study. This approach is the observation during conducting the interviews which researcher used in this study. It was the second way of collecting data in this study depending on qualitative method. Type of qualitative method was not according to previous observations or classifications, but the researcher used direct observation and wrote the notes based on the real facts in the ground. Researcher had visited the head office of both Muhammadiyah and Nahdlatul Ulama in Jawa Timur (Malang) and asked them for documents and references related to both organizations. Every organization gave some books and other information and websites to support researcher to collect needed data for this study.

\subsection{Purposive Sample}

There are many types of purposive sampling where researcher chose typical case sampling to conduct this study. Typical case sampling is a type of purposive sampling useful when a researcher wants to study a phenomenon or trend as it relates to what are considered "typical" or "average" members of the effected population. Criteria: In this study, two head offices of Muhammadiyah and Nahdlatul Ulama, tow specialists were selected from both organizations and three scholars of every organization were chosen as well in addition to scholars in the field. The interview was a semi-structured interview with open-ended questions. The interview were designed as it is open questions to provide more flexibility to the researcher to ask additional questions when needed and the method of design of questions helps participants to provide more information to the researcher. 


\subsection{Data Analysis Approach}

Qualitative research is development of concepts which help us to understand social phenomena in natural (rather than experimental) settings, giving due emphasis to the meanings, experiences and views of the participants (Pope \& Mays, 1995). Giorgi's model was used in data analysis. In general, the model of Giorgi $(1975,2009)$, where he stated that phenomenologists seeking to explicate "lived experience", must do justice to the phenomenon studied; research method needs to be responsive to the phenomenon, to be true to its integrity towards capturing something of its "is-ness" (Giorgi, 1975).

\section{Results}

This study contributes an important concept about Muhammadiyah and Nahdlatul Ulama as religious and social organizations. Rational choice theory was tested by the followers of both organizations. The impact of these organizations in political and social life of Indonesian society was determined by some social, cultural, religious and political factors. Study contributes the following:

First: Characteristics of Organizations: Characteristics of Muhammadiyah and Nahdlatul Ulama could be divided into two types: common and different characteristics. Muhammadiyah and NU are similar in social service, religious orientation and Islamic education. Both organizations share the same Islamic values regardless some differences in doctrines. There are some differences where Muhammadiyah is considered as Modern organization, revolutionary and renewal movement while NU has strong believe in the founders thoughts where no change in the basics of these thoughts and modern in education, politics and some social activities. Muhammadiyah and NU have the same sense to the country values and role of secular government where both organizations accepted Pancasila as background for all Indonesian people. Muhammadiyah keeps in renewing the local culture and Islamic thoughts while NU is strict in Islamic thought and integrating local culture with Islamic beliefs. Both organizations have a political party but they don't stand behind these parties all the time where some members support them while other members join another political party. Muhammadiyah followers are more rational while NU followers are more emotional (Figure 1).

Second: Rational Choice: According to Coleman theory of rational choice, there are three motivators behind following any organization which are psychological, economic and political factors. This study included five factors which are values, family, education, society and benefits. Difference in these factors shows the different interest of people based on the cultural, social and religious backgrounds. Values of the organizations include social and political interest as well. Benefits also include the social and political position for the member of the organization. Values of the organization and education have the priority in $\mathrm{Mu}$ hammadiyah while family and values have the priority in Nahdlatul Ulama respectively (Figure 2). 
Third: Social Impacts: Muhammadiyah and Nahdlatul Ulama have a significant impact on the Indonesian Muslim society. In addition, both organizations play important role in conducting socio-religious and socio-cultural occasions. The way of implementing such social impact is done by holding religious activities, education, cultural events and charity. As an Islamic social organization in a Muslim majority population country, both organizations share the most Islamic values and differ of few. Some of these socio-religious events as guiding people in mosques, conducting Maulid Nabawi, and other religious occasion such as marriage, fasting and funeral gathering. They differ in some these habits such as Tahlilan, Yasinan, Halal bihala and visiting Makams (Figure 3).

Forth: Political Impacts: Muhammadiyah and Nahdlatul Ulama are not political parties but they play a significant role in shaping the Indonesian politic. Activists of both organizations have formed political parties but not all followers of the both organizations follow these parties. First political party was formed by two organizations was named Masyumi to defense the identity of the Islam in Indonesia during colonial time. After that time, every organization has its own agenda to serve people and strengthen the Islamic culture in the country. $\mathrm{Mu}$ hammadiyah and Nahdlatul Ulama are working together like a balance in the politic. After 1998, every organization has independent political party (PKB and PAN). Based on their participation in presidential elections, every organization chose different candidates. Only one time in 2004 where two organizations had supported the same candidate to win the presidential elections (Figure 4).

\begin{tabular}{|ll|}
\hline$*$ Similarities & $*$ Differentiations \\
\hline Characteristics of Muhammadiyah \\
\hline - Religious Orientation & $*$ Renewal Movement \\
- Social Service & $*$ Pure Islamic Culture \\
- Islamic Education & $*$ Rational Followers \\
\hline Characteristics of Nahdlatul Ulama \\
\hline \begin{tabular}{ll} 
- Religious Orientation & $*$ Traditional Movement \\
- Social Service & $*$ Mixed Culture \\
- Islamic Education & $*$ Emotional Followers \\
\hline
\end{tabular}
\end{tabular}

Figure 1. Comparison of muhammadiyah and NU.

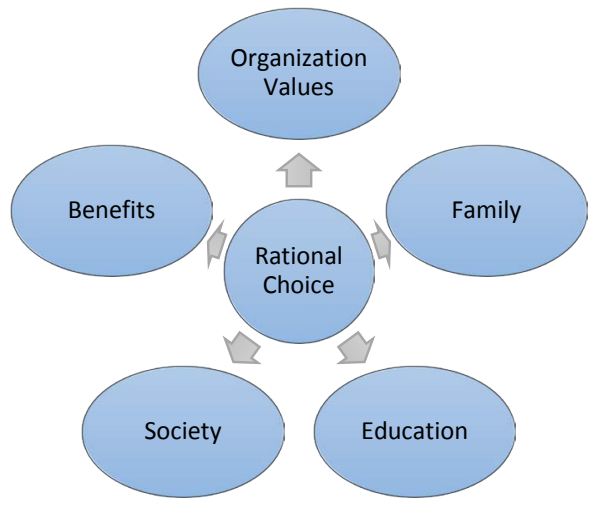

Figure 2. Rational choice in both organizations. 


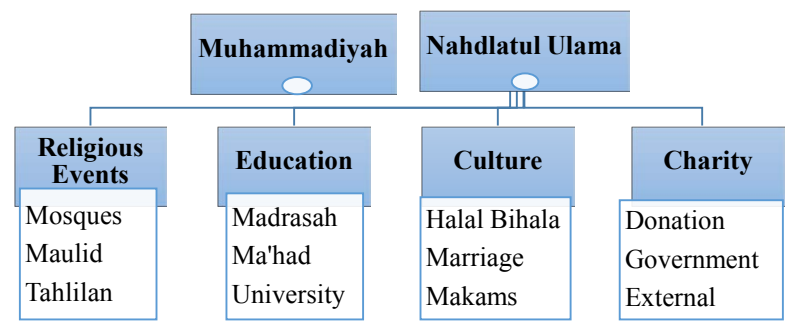

Figure 3. Social aspects of muhammadiyah and NU.

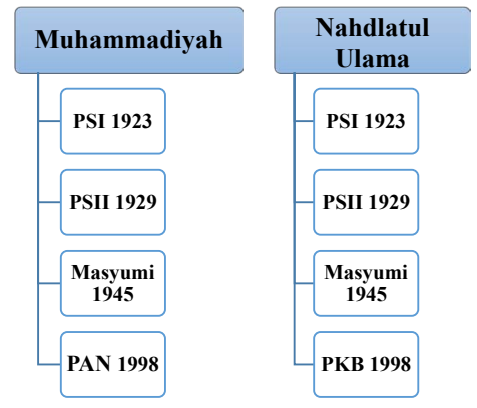

Figure 4. Politics in muhammadiyah and NU.

\section{Discussion}

Muhammadiyah and Nahdlatul Ulama have many similarities and some differences. They are the same at the basic level and the origin of finding in addition to the Islamic thoughts while they have some differences at the additional thoughts and some activities. Muhammadiyah has ideology of (Dakwah) and (renewal), without being stuck and adhering to a culture that does not match what was taught by the Prophet Muhammad, which is ultimately an autobiographical image of Muhammadiyah throughout its history. This movement also has a desire to continue to make every effort to achieve the life of the nation so that not only does Muhammadiyah provide a temporary pragmatic value to the people, it also encourages the building of community awareness for the most advanced and better within Islamic values. Nahdlatul Ulama is a movement that preserves the practices or traditions of Islam in the archipelago. This movement largely respects all that has been distributed and supported by those who have passed through. Certainly remain in the nuances of Islam. Therefore, NU opposed the renaissance of scholars of Muhammadiyah ideology because of differences in perspective in the practice of the teachings of Islam. NU Ideologies that are compatible with the values of local culture make the renaissance of scientists alive because of the nature of this movement, which is more readily accepted by the public. In the case of fiqh, Nahdlatul Ulama set out to follow the four schools in favor of the people. They are Shafi'i, Maliki, Hanafi and Hanbali with the majority of NU follow-up Shafei School. That is, NU appeared as a guardian of the continuity of tradition and the teachings of the four schools and the faith of Ahlusunnah wal Jama'ah. It also contains a set of beliefs about the schools of faith, jurisprudence and mysticism agreed upon (Table 1). 
Table 1. Characteristics of muhammadiyah and nahdaltul ulama.

\begin{tabular}{|c|c|c|c|}
\hline No. & Concepts & Muhammadiyah & Nahdlatul Ulama \\
\hline 1. & Establishment & 18 November, 1912 & 31 January, 1926 \\
\hline \multirow[t]{2}{*}{2.} & Founder & KH. Ahmad Dahlan & KH. Hasyim Asy’ari \\
\hline & & & Abdul Wahab Hasbullah \\
\hline 3. & Place & Kauman, Yogyakarta & Surabaya \\
\hline 4. & Followers & 40 million & 90 million \\
\hline 5. & Education & Madrasah & Pesantren \\
\hline 6. & Belief & Salafism & Ahlusunnah wal Jama'ah \\
\hline 7. & Islamic Sect & No Islamic Sect & Shaf $i$ \\
\hline 8. & Woman Org. & Aisyiyah & Muslimah \\
\hline 9. & Ideology & Renewal & Traditional \\
\hline
\end{tabular}

Muhammadiyah and Nahdlatul Ulama have accepted Pancasila as an essential part of the organization basics. Pancasila closes distance between Indonesian parties, organizations and origins. The fact is that relations between the NU and Muhammadiyah have grown increasingly close, especially with regard to the issue of Islamic thought and moderate/inclusive behavior, which these two main wings of Indonesian Islam carry upon their shoulders. The two organizations share the same views about Islam, humanity and Indonesian nation. This positive development is highly significant for the future of Indonesia, for the NU and Muhammadiyah no longer need to waste more time debating Pancasila as the foundation of nation state.

Nahdlatul Ulama and Muhammadiyah have important activities of the entire heart of the Muslims of Indonesia and neighboring countries (such as Malaysia, Singapore, Thailand, Philippine, Brunei and China), not only as a social institution, but also the religious center of Dawah, schools, as well as other important agendas related to people. Some of international agenda of Dawah have been spread to Middle East countries such as Egypt, Yemen and Afghanistan. With increasing of understanding of Islamic society in Indonesia happens nowadays, Muhammdiyah and NU as institutions, its existence are important for Muslims not only focuses on religious activities, but also developed with social as well as economic activity reviving such as education institutions from elementary to colleges, hospitals, cooperatives, baitul maal wat tamwil, and others.

Muhammadiyah and NU is expected to be an inspiration for the world in the midst of a global life situation, economic domination, capital and global terrorism network issues. Muhammadiyah and NU as the largest Islamic organizations in the country has established their determination to spread Wasatiyah Islam (Moderate Islam). Of course the socialization is not only in Indonesia but can spread throughout the region and all of the world.

The reasons of choosing Muhammadiyah and NU are almost the same with little difference in priorities. Muhammadiyah's followers gave values and education the priority while $\mathrm{Nu}$ gave to the family and society. These results show the differences of characters of every organization. Most followers of Muhammadiyah make their decision rationally while NU followers make their decision 
emotionally. There is another fact behind this choosing where most of Muhammadiyah followers are educated enough and living in urban while Most of NU followers are living in villages and countryside. This shows that NU followers are affected by family and society more than education or values of the organization. They don't want be exulted of the society so they follow the same traditions and social activities. While Muhammadiyah followers are living in cities where people are not strongly connected to each other or feel they will not be part of the society if they didn't follow these activities.

\section{Conclusions}

Muhammadiyah and Nahdlatul Ulama are the biggest Social Islamic organizations in Indonesia. These organizations play a significant role in social and political aspects of Indonesian society. This study has concluded four important concepts about two organizations as:

1) Muhammadiyah and Nahdlatul Ulama share same values as they are religious, social and educational organizations and differ in some sub-issues in religion and Islamic path. Muhammadiyah was known as reformist and modern while NU was known with traditions but they are now at the same level introducing moderate Islam.

2) Rational choice of following Muhammadiyah and NU was based on five motivators which are values of the organization, Family background, Education, society orientation and related Benefits. Values and education have the priority in Muhammadiyah while family and values have the priority in NU respectively.

3) Known as social organizations, Muhammadiyah and NU play an important role in social life of Indonesian people. Both organizations impact on society by education, socio-religious, cultural and charity factors. Thousands of Islamic schools, hundreds of Islamic universities, thousands of mosques, health care centers, hotel and tourism and hundreds of businesses centers are owned by these two organizations. In addition, Muhammadiyah and NU hold continuous social and cultural conferences for than a hundred million of followers and public.

4) Muhammadiyah and NU together had formed Masyumi political party which was the biggest political party in the country. This party cooperated with national parties against communists and other parties to keep the identity of Islam in Indonesia. Members of both organizations lead Islamic parties and participate in many national parties where they have important role in legislative, presidential and local elections.

\section{Recommendations}

Recommendations of this study include some suggestions for the two Islamic organizations Muhammadiyah and Nahdlatul Ulama.

1) Relationship between Muhammadiyah and Nahdlatul Ulama is very important to keep the peace in Indonesia and there is a need for more discussion between leaders of both organizations about religious and political issues. 
2) Muhammadiyah and Nahdlatul Ulama have a religious and national duty to support and spread tolerance with other religions related to diversity in the country.

3) As an Islamic social organization, Muhammadiyah and NU need to promote this moderate Islamic ideology internationally.

4) Muhammadiyah and Nahdlatul Ulama have a clear opinion against radical Islamic groups but they still have to work more to attract young Muslims who were interrupting in hostile acts against the state and some minorities.

\section{Conflicts of Interest}

The authors declare no conflicts of interest regarding the publication of this paper.

\section{References}

[1] Statistik, B.P. (2010) Population by Region and Religion. Sensus Penduduk 2010. Badan Pusat Statistik, Jakarta.

[2] Abdullah, T. (1983) Agama dan Perubahan Sosial. Rajawali Press, Jakarta.

[3] Cassidy, J. (2008) Economics: Which Way for Obama? Review of R.H. Thaler and C.R. Sunstein, New York Review of Books June 12, 2008, 30-34.

[4] Pew (2015) Chapter 1: Religious Affiliation. The World's Muslims: Unity and Diversity. Pew Research Center's Religion \& Public Life Project.

[5] Ishomuddin (2014) Construction of Socio-Cultural and Political Orientation of the Followers of Muhammadiyah and Nahdlatul Ulama (NU) in the Post Reform Era in East Java Indonesia. Global Journal of Politics and Law Research, 2, 39-51.

[6] Kuda, F. (2017) The History of Muhammadiyah's Thought and Movement, Study on Personality and Idea of the Founding Figure (KH. Ahmad Dahlan).

[7] Hasbullah, M. (2014) A Century of NU-Muhammadiyah in Indonesia: The Failure of Islamic Modernism? Islamika Indonesiana, 1, 17-21. https://doi.org/10.15575/isin.v1i1.2

[8] Fiorina (2001) International Encyclopedia of the Social \& Behavioral Sciences.

[9] Eells, E. (2016) Rational Decision and Causality. Cambridge University Press, Cambridge. https://doi.org/10.1017/CBO9781316534823

[10] Restaki, J. (2006) Defining the Social Economy: The BC Context.

[11] Brown, C. (2003) A Short History of Indonesia. Allen \& Unwin, Crows Nest.

[12] Grattan, H. (1963) The Southwest Pacific since 1900. University of Michigan Press, Ann Arbor, 452.

[13] Paasman, G.O.B. (1998) Dutch Attitudes towards Colonial Empires, Indigenous Cultures, and Slaves. Eighteenth-Century Studies, 31, 349-355. https://doi.org/10.1353/ecs.1998.0021

[14] Kusuma, A. and Elson, R. (2011) A Note on the Sources for the 1945 Constitutional Debates in Indonesia. Journal of the Humanities and Social Sciences of Southeast Asia, 167, 196-209. https://doi.org/10.1163/22134379-90003589

[15] Ricklefs, M.C.A. (1993) History of Modern Indonesia since c. 1300. 2nd Edition, MacMillan, London. https://doi.org/10.1007/978-1-349-22700-6 